\section{Science versus anti-science}

SIR - John Maddox's article about antiscience (Nature 368, 185; 1994) raises a fundamental issue: how to counter the increasingly vocal fringe of society pumping energy into the preconceptions of the majority.

I have no formula to offer, and can only suggest that a closer definition of the focus of majority fears might help science to find an antidote to stop the rot while efforts are mounted to bridge the abyss of ignorance.

It appears to me as a moderately informed observer - for 35 years from within the chemical industry - that the long-standing equilibrium between "religion and astrology etc." on the one hand and rational objectivity on the other became unstable at about the time that science began to express serious concern about the impact of humanity on the life support systems of the planet.

This equilibrium between irrational subjectivity and rationality had, since time immemorial, been mediated essentially by intellectuals of one persuasion or another. Clearly it has shifted since the days of Thomas Aquinas, but by the end of the nineteenth century it was still the basic condition in which philosophical discourse took place. Religion had conceded a great deal of ground, not least to Copernicus, but was still recognizable as a major force in evolute societies; elsewhere, it remained the principal controlling factor of human emotion and of enquiry.

The last decades of the twentieth century brought us two entirely novel influences that have upset the equilibrium: worldwide communications and the awareness of humanity as a potentia danger to itself. Science alone conjured these factors out of its deepest thinking, and in so doing has assumed responsibility for many of the longer-term consequences. Furthermore, the characterization, as it were by definition, of many aspects of human behaviour in evolute societies as contrary to Darwinian principles has led to defensive postures more strident than those related simply to arguments about population growth and survival of the fittest.

It should not surprise us, then, that the multitudes dislike the message, nor that there are those who exploit the communication miracle to broadcast fears and fantasies and emotive prescriptions for peace, prosperity and fulfilment. The prescription is: "Kill the messenger!"

To make matters worse, science is seen to have arrived with dirty boots, so it may well take more than a polemicist to avoid its lynching. Nothing less than a convincing assurance that it can "Save the Planet for Life" will suffice. Taking its cue from politics, science must make upbeat prom- ises, preferably ones it can deliver in the short term, in a comprehensible language. Then, if the rot can be stopped, science must concentrate on building bridges to help mankind step across the abyss.

D. A. A. Fagandini

6 Alleyn Park,

London SE21 8AE, UK

SIR - Maddox pleads passionately for a more polemical defence of science against anti-science. While sympathizing with his concern, I wonder if his proposed strategy would serve the intended purpose. Will science benefit from lowering itself onto the battlefield of its presumed enemies? Let's face it: astrology is at least as old as science, whatever definition you choose for that noble endeavour. Science has flowered all along, with ups and down, in spite of the presence of the irrational. I refuse to believe that religion and superstition compete with science in the same market for whatever livelihoods one might consider. What I regard as true science has always distinguished itself from such sectarian pursuits by its openness to challenge, its lack of fanaticism and its disunity (see J. Dupré, The Disorder of Things, Harvard Univesity Press, 1993).

Irrespective of these issues of dignity, the present crisis of science is not due to recrudescence of anti-science. If anything, it's the other way round. The flattering public support of the scientific enterprise has its roots in the prevailing (relative) peace. War has always been - directly or indirectly - the single most important stimulant for science, materially but also by spurring inventiveness. Enlightenment may be what scientists cherish most by way of reward for their labour, but people and governments tend to favour more prosiac motives. As a scientist and a pacifist I thus find myself in a severe dilemma Maybe what is needed now for scientists to save their cause is a lesson in humility.

\section{Werner Sieber}

rue du Botzet 3 ,

1700 Fribourg, Switzerland

SIR - Maddox writes that: "As the long (and soon to end) correspondence in Nature has shown, many professional scientists are deeply religious, often justifying their belief on the grounds that 'science cannot know everything." 'Later in the same paragraph, he writes, “. . . it may not be long before the practice of religion must be regarded as anti-science".

Where does Maddox propose to draw the line? If Nature views religious scientists as anti-scientific, will this make all their scientific work suspect and therefore unworthy of publication?

Elsewhere in the same issue is a review by David Knight of two books about Robert Boyle (368, 200; 1994) which describes Boyle's well-known Christian faith. Does this make the famous chemist anti-scientific in the eyes of Nature? Many papers in the same issue use nomenclature devised by Linnaeus, another devout Christian. Finally, the sales office of Nature printed in the same issue as Maddox's remarks (Classified page 32) an announcement of deadlines altered "Due to the Easter recess. ...".

If Nature plans to draw the line in religion, then those of us who faithfully subscribe and occasionally contribute to its pages, but who also happen to be religious, need to know precisely where the line is to be drawn.

Forrest M. Mims III

433 Twin Oak Road

Seguin, Texas 78155, USA

SIR - You serve warning that to defend against anti-science you would end the "disgraceful... benign tolerance" afforded not only to astrology, but also to "exaggerated arguments" over nuclear power and genetics. Most strikingly, you observe that "it may not be long before the practice of religion must be regarded as anti-science".

How long, Sir? Some of us will need to know when to submit our manuscripts elsewhere, lest our practice of religion indicates to you that we regularly perpetrate "a pack of lies" (like astrology) or "false statements" (like those exaggerators). Shall your Guide to Authors soon require that we disclose our religious affiliations?

You say that the long correspondence on religion in Nature is "soon to end". How sad that your last word is a polemic attack on the religious among your readers and authors.

\section{Peter Vibert}

RosenstielBasic Medical

Sciences Research Center,

Brandeis University,

Waltham, Massachusetts 02254, USA

SIR - Mario Vaneechoutte (Nature 365, $290 ; 1993)$ refers to religion as a meme. The adjective "memetic" and the noun "meme" do not appear in the Oxford English Dictionary. There is little doubt that Richard Dawkins is the originator of the noun in 1976 in his famous book The Selfish Gene. This work is reprinted and is easy to find (1989). The definition of "meme" is on page 192. He defines it as a non-genetic replicator that flourishes only in the environment provided by complex brains. Personally I think Vaneechoutte is correct in his analysis of a complex question.

\section{Frank W. Cousins}

43 Emanuel House,

18 Rochester Row,

London SW1P 1BS, UK 